\title{
Determinants of Knowledge Sharing Behaviour among Personnel in Banking Industry
}

\author{
Kholoud I. Al Qeisi ${ }^{1}$ \& Hanadi M. Al Zagheer ${ }^{2}$ \\ ${ }^{1}$ Marketing Department, Applied Science University, Shafa Badran, Amman, Jordan \\ ${ }^{2}$ MIS Department, Applied Science University, Shafa Badran, Amman, Jordan \\ Corresponding: Kholoud Al Qeisi, Marketing Dept., Applied Science University, Shafa Badran, Amman 11931, \\ Jordan. Tel: 962-777-190-558. E-mail: k.alqeisi@gmail.com
}

Received: January 23, 2015

Accepted: February 6, 2015

Online Published: March 27, 2015

doi:10.5539/ijbm.v10n4p49

URL: http://dx.doi.org/10.5539/ijbm.v10n4p49

\begin{abstract}
The paper aims to examine determinants of knowledge sharing behaviour among personnel in Jordanian commercial banks under the umbrella of the Theory of Planned behaviour (TPB). Data is collected from branches located in the capital's geographical area using self administered survey in a cross sectional design. 218 usable responses are tested with confirmatory factor analysis. The analysis revealed a weak representation of the subjective norms variable at the measurement model level. The structural model is tested with the three remaining variables. The results indicate that intention to share knowledge among personnel in Jordanian banks is mainly influenced by perceived behavioural controls followed by attitude. Findings indicate Females' knowledge sharing behavior is motivated exclusively by perceived behavioural controls through behavioural intention. This result indicates the need to develop more favourable attitude towards knowledge sharing among female personnel at Jordanian banks; nevertheless, the findings need to be confirmed using a larger sample and a longitudinal study.
\end{abstract}

Keywords: TPB, knowledge sharing, gender, commercial banks, Jordan, SEM

\section{Introduction}

Organizations are increasingly recognizing knowledge as the most valuable resource and the best basis for improving a competitive edge (Argote \& Ingram, 2000). Fundamentally, knowledge management refers to making the right knowledge and its sources available to the right people on time. A remarkable character of knowledge is that its value increases when employees have direct access to and actually use and share (Smith, 2001), which makes knowledge sharing the most important dimension of knowledge management (Bock \& Kim, 2002). However, the success of knowledge management initiatives depends on knowledge workers' ability and willingness to participate, seek out, or be receptive to knowledge sources (Frost, 2014). Accordingly, monitoring and encouraging knowledge sharing among workers is imperative to maintain a competitive edge. Therefore, examining determinants of actual knowledge sharing behaviour and employees' motivational intentions to engage in knowledge sharing behaviours is essential.

Extant research explains individuals' behaviour motivation and usage intentions: Theory of Reasoned Action (TRA) is among the earliest model employed to explain individuals' behavioural intention, and its revision Theory of Planned behaviour (TPB), which involves the addition of one major predictor to the model, perceived behavioural control. This addition was made to account for times when people have the intention of carrying out behaviour but the actual behaviour is thwarted based on lack of confidence or control over behaviour (Miller, 2005, p. 127).

The current research is an exploratory study based on the survey using a sample from personnel working at commercial banks in Jordan. The paper investigates determinants of actual knowledge sharing (KS) behaviour among male and female personnel under the framework of theory of planned behaviour. Previous research acknowledges gender differences with respect to technology acceptance behaviour in general; however, research focused on gender differences is still evolving in knowledge sharing area. The current paper aims to contribute to knowledge by exploring whether gender differences exist among banking personnel knowledge sharing behaviour in Jordan's commercial banks. 


\section{Theoretical Background}

\subsection{Reasoned Action/Planned Behaviour}

The Theory of Reasoned Action, TRA, as depicted in Figure 1 by (Ajzen \& Fishben, 1980) posits that an individuals' voluntary behaviour is predicted by their attitude towards that behaviour and how they think other people would view them if they performed the behaviour. In other words, individuals' behavioural intentions are dependent on their attitude about the behaviour and subjective norms; however the two variables are not equal in predicting intentions; rather the outcome relies on the individuals and situations. Attitude towards an act or behaviour refers to the individual's positive or negative feelings about performing the behaviour, determined through an assessment of one's beliefs.

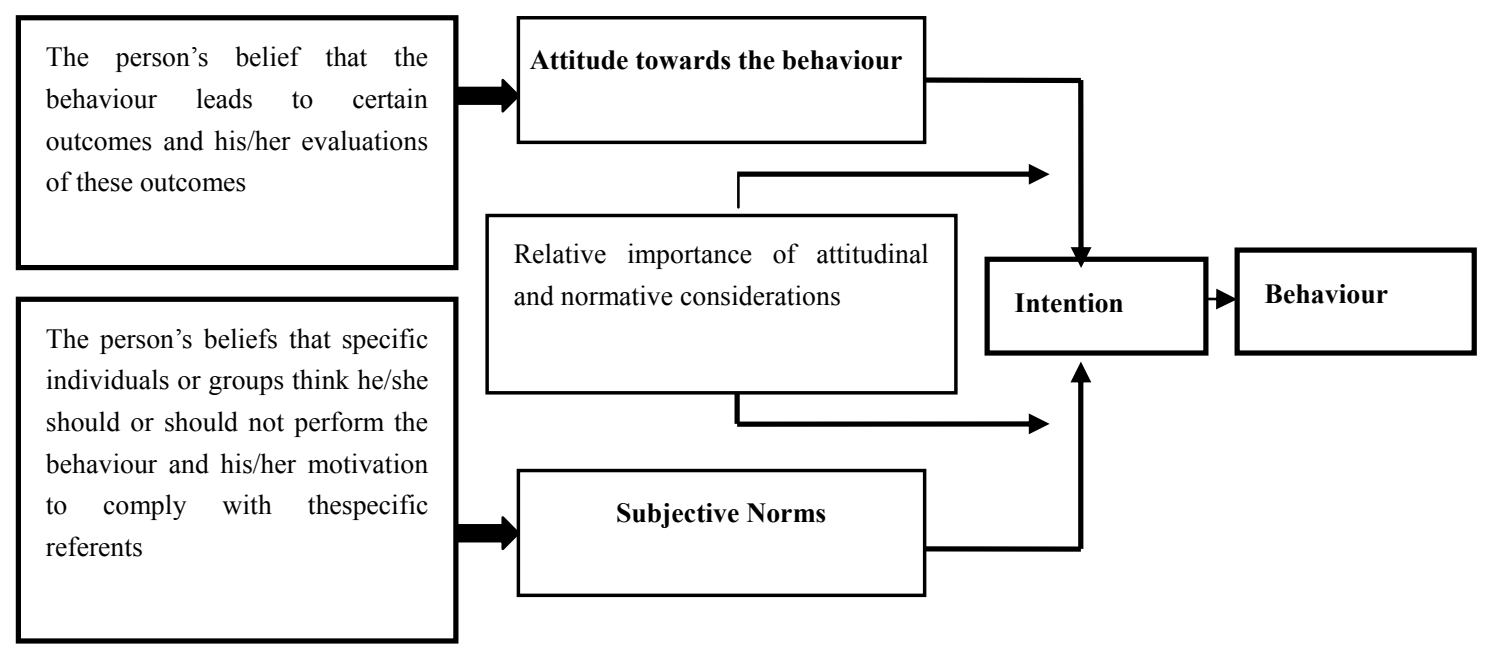

Figure 1. Theory of reasoned action

Source: Ajzen and Fishben (1980).

Subjective norm, on the other hand, is an individual's perception of whether people important to the individual think the behaviour should be performed. Intention is an indication of an individual's readiness to perform a given behaviour, and it is considered to be the immediate antecedent of behaviour.

Ajzen and Fishbein (1985) noted that the theory was limited by what they call correspondence. In order for the theory to predict specific behaviour, attitude and intention must agree on action, target, context, time frame and specificity (Sheppard, Hartwick, \& Warshaw, 1988). A major limitation of the theory is the assumption that behaviour is under volitional control; namely, the theory only applies to behaviour that is consciously thought out beforehand. In order to overcome this limitation, Ajzen (1985) extended TRA into the Theory of Planned Behaviour (TPB) by incorporating the perceived behavioural control (PBC) variable to account for situations where an individual has less than complete control over the behaviour. PBC refers generally to individuals' expectations regarding the degree to which they are capable of performing a given behaviour and the extent to which they have the pre-requisite resources, internal or external (Ajzen, 2002). The TPB places the PBC within a more general framework of relations among attitude, intentions and behaviour and the added $\mathrm{PBC}$ variable is held to influence both intention and behaviour. Although Ajzen (2006) acknowledges major limitations of TPB, for instance, the model does not address actual controls over behaviour or the time frame between intent and behavioural action; the model applicability in explaining diverse behaviours has been indicated by literature (Sheppard et al., 1988; Armitage \& Conner, 2001).

\subsection{Knowledge Sharing and Individual Behaviour}

Knowledge is referred to by Webster dictionary as the human theoretical or practical understanding of a subject; acquired through study, observation, experience, or investigation (Wang, Hjelmervik, \& Bremdal, 2001). Knowledge can be divided into two types: explicit and tacit. Data and information, which is encoded, stored and disseminated is referred to as the content component of knowledge, the explicit part. Tacit knowledge is the context component of knowledge referred to as the mind-set of individuals, which includes intuition, values and beliefs stemming from experience (Awad \& Ghaziri, 2007). Knowledge sharing is also the provision of task 
information and know-how to help others and to collaborate with others to solve problems, develop ideas, or implement procedures or policies (Wang \& Noe, 2010). In organizational context, knowledge sharing is define as the sharing behaviour of organizationally relevant experiences, important information, management beliefs, and contextualised practices among employees (Lin, 2007).

Literature reports knowledge sharing impediments within an organizational context at different levels: individual, team, unit and department (Wang \& Noe, 2010). The current paper investigates knowledge sharing on the most basic level, the individual. In this context, knowledge sharing is defined as the process by which individual employees impart their expertises, insights, or understanding to other individual employees, who may acquire and use the knowledge to perform the tasks required. Alternatively, knowledge sharing is a process by which knowledge held by one individual is converted into a form that can be understood, absorbed and used by other individuals (Ahmadi, Daraei, \& Kalam, 2012).

Knowledge sharing is influenced by the complex social context or interpersonal relations within organizations (Cross, Parker, \& Borgatti, 2002). However, due to the nature of knowledge (explicit and implicit) in addition to individuals' diverse abilities and motivation, knowledge sharing is not necessary an impulsive behaviour (Kelloway \& Barling, 2000). Organizational context, interpersonal characteristics, cultural characteristics, and individual characteristics (Wang \& Noe, 2010; Ipe, 2003) are among cited impediments to individuals knowledge sharing or hoarding behaviour. Previous research reports employees' attitude as an imperative factor in practicing knowledge sharing (Hislop, 2003). An attitude probably built on past experiences or formed in realizations of positive/ negative possible outcomes of sharing behaviour. For example, devolution of power and job security or fear of redundancy (Bender \& Fish, 2000, Martensson, 2000, Miller, 2002): knowledge perceived as a source of power (Dunford, 2000; Grandori \& Kogut, 2002; Goman, 2002) makes some individuals reluctant to share. Likewise, dependency and inferiority (Yang, 2008): employees fear looking less knowledgeable and dependent on others for knowledge, which leads to the feeling of inferiority in their social context. Rivalry and jealousy as well impedes knowledge sharing and leads to knowledge hoarding (Arora, 2002; Wah, 1999) and finally, being unaware of the value of someone's knowledge to others (Martensson, 2000; O'Dell \& Grayson, 1998).

Literature on technology based knowledge management systems also reports gender behavioural dissimilarities. Females are less likely to use knowledge management systems and males use data mining function more often than females (Taylor, 2004). Sawng, Kim, and Han (2006) report females have greater participation in knowledge sharing than males. Females perceive allocating more time for tacit knowledge than males (Luethge \& Byosiere, 2007). Female employees perceived knowledge sharing culture differently than their male counterparts: the more positive their perception of social interaction culture, the more likely they are to share knowledge (Connely \& Kelloway, 2003).

\section{Research Model and Hypotheses}

The proposed research model (Figure 2) is built upon the TPB model with adaptation to investigate determinants of knowledge sharing behaviour among personnel in Jordanian banks, namely attitude, subjective norms, and perceived behavioural controls. The proposed model is focused on behaviour within the organizational context.

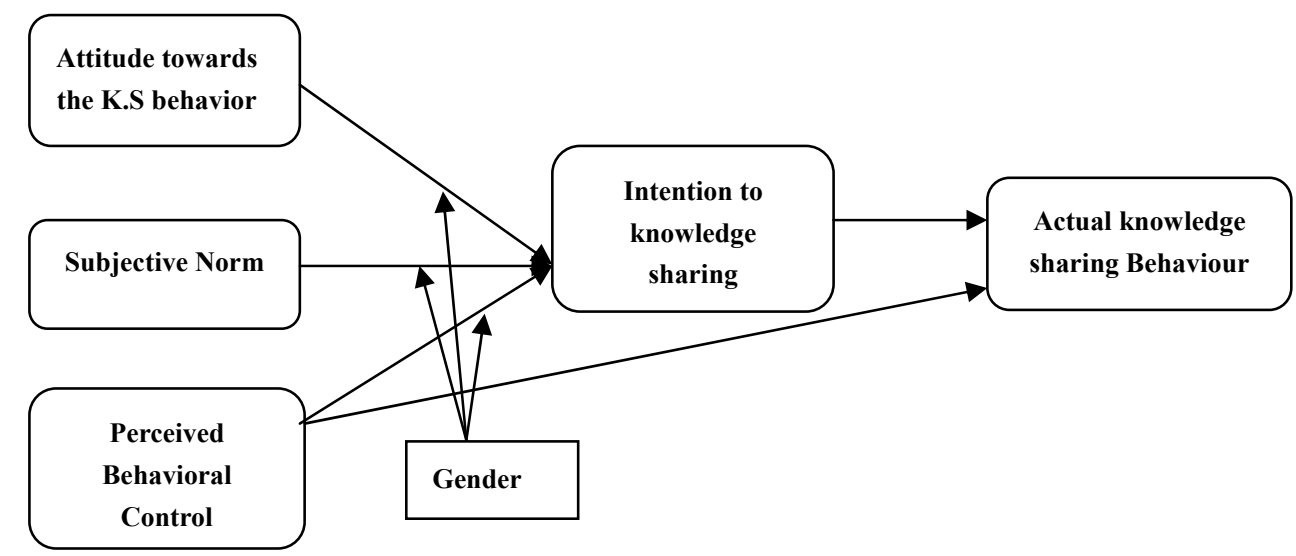

Figure 2. Research model 


\subsection{Attitude towards Knowledge Sharing}

Evidence from previous research on knowledge sharing under TRA and TPB umbrella relate attitude towards knowledge sharing directly and positively to knowledge sharing intention (Lin \& Lee, 2004; Bock, Zmud, Kim, \& Lee, 2005; Chatzoglou \& Vraimaki, 2009; Alhalhouli, Hasan, \& Der, 2014).

H1: Positive attitude towards knowledge sharing will positively impact intentions to share knowledge and, consequently, sharing behaviour

\subsection{Subjective Norms}

According to the TRA/TBP model, when an individual perceives that significant others endorse the knowledge sharing behaviour, the individual is more likely to intend to share knowledge. Previous research shows support to this impact (Lin \& Lee, 2004; Chatzoglou \& Vraimaki, 2009; Mahmood, Qureshi, \& Shahbaz, 2011; Jeon, Kim, $\&$ Koh, 2011).

H2: Subjective norms will positively impact intentions to share knowledge and, consequently, sharing behaviour.

\subsection{Perceived Behavioural Controls}

According to TPB, perceived behavioural controls enhance individuals' intentions because individuals tend to accomplish only the tasks that they believe they can perform successfully. Literature reports support to the perceived behavioural controls and knowledge sharing intention relationship (Lin \& Lee, 2004; Alhalhouli et al., 2014).

H3: Perceived behavioural controls will positively impact intention to share knowledge.

Additionally, TPB reports perceived behavioural controls direct impact on behaviour.

H4: Perceived behavioural control will directly impact knowledge sharing behaviour.

\subsection{Gender and Knowledge Sharing}

Literature on knowledge management in general and knowledge sharing in particular has rarely tackled gender differences although gender differences in information systems have been documented. For example, Venkatesh and Morris (2000), Venkatesh, Morris, and Ackerman (2000), and Morris, Venkatesh, and Ackerman (2005) report gender differences with respect to decision making process. Females behavioural intentions were mostly motivated by attitude, social norms and perceived behavioural controls, whereas, males were only motivated by attitudinal beliefs. Accordingly, it is hypothesized:

H5: Gender will moderate the relationships among the TPB constructs.

More specifically:

H5.1: Attitude- behavioural intention will be stronger for males than females.

H5.2: Social norms-behavioural intention will be stronger for females than males.

H5.3: PBC-behavioural intention will be stronger for females than males.

\section{Methodology}

\subsection{Sampling and Data Collection}

Samples were extracted from ten (out of the thirteen Jordanian commercial banks) in the capital Amman and within branches at different locations in Amman's geographical area. The research instrument was written both in English and Arabic; multilingualism (English, Arabic) is a job requirement for bankers in Jordan. Translation was used for clarifying conceptual terminology. Prior to collecting data, the research instrument was tested using a sample of top level and technical level bankers to ensure clarity and understanding. The operational definition of the variables and scaling is based on Ajzen (2002) guidelines for structuring a TPB questionnaire and previous research (e.g., Bock \& Kim, 2002; Lin \& Lee, 2004; Chatzoglou \& Vraimaki, 2009) adjusted to the technology under investigation, knowledge sharing (Appendix).

The sample size was determined based on the number of parameters in the research instrument multiplied by ten, which results in two hundred. With a return rate of $75 \%$ only 218 were usable after excluding the incomplete ones. 
Table 1. Sample demographics

\begin{tabular}{lllll}
\hline Demographics & Descriptions & Frequency & percentage & Cumulative percentage \\
\hline Job Title & Manager & 40 & 18.3 & 18.3 \\
& Deputy manager & 36 & 16.5 & 34.9 \\
& Department head & 26 & 11.9 & 46.8 \\
& Deputy department head & 15 & 6.9 & 53.7 \\
& Clerk & 95 & 43.6 & 97.2 \\
& Others & 6 & 2.8 & 100.0 \\
\hline Education & Doctorate & 4 & 1.8 & 1.8 \\
& Masters & 38 & 17.4 & 19.2 \\
& Higher Diploma & 29 & 13.3 & 32.5 \\
& Bachelor & 118 & 54.1 & 86.7 \\
& Diploma & 28 & 12.8 & 99.5 \\
& High school and below & 1 & .50 & 100.0 \\
\hline Experience & $1-4$ yrs & 66 & 30.3 & 30.3 \\
& 5 -9 yrs & 85 & 39.0 & 69.3 \\
& 10 yrs and more & 67 & 30.7 & 100.0 \\
\hline Gender & Male & 140 & 64.2 & 64.2 \\
& Female & 78 & 35.8 & 100.0 \\
\hline
\end{tabular}

Table 1 illustrates the demographics of the sample: majority are experienced in the banking sector $(70 \%$ enjoy 5 to more than 10 years experience and $30 \%$ have up to 4 years experience). The sample is educated as well (54\% with a bachelor degree while $31 \%$ have a higher education degree). Females comprised $36 \%$ of the sample, while males predominated, with $65 \%$. Finally, the sample consists of only $44 \%$ of non-managerial workers whereas the majority, $64 \%$ assume managerial roles.

\section{Data Analysis}

Prior to conformity factor analysis, data was screened and treated for missing data using mean imputation since the rate was below 5\%. Normality assessment using AMOS output indicated acceptable levels of univariate normality (kurtosis values $<7$ ) and multivariate normality (critical value 4.217). The assessment of multivariate outliers using the mahalanobis distance (d-square) showed minimal evidence of serious multivariate outliers based on Byrne (2010, pp. 104-106) guidelines.

\subsection{Measurement Model}

Three loading of subjective norms variable have loadings below the standard acceptable threshold (.5) of standard regression weights and squared multiple correlations which resulted in eliminating social norms from the model. Other parameters also were below the standard acceptable threshold and were eliminated. Figure (3) illustrates the measurement model after refinements.

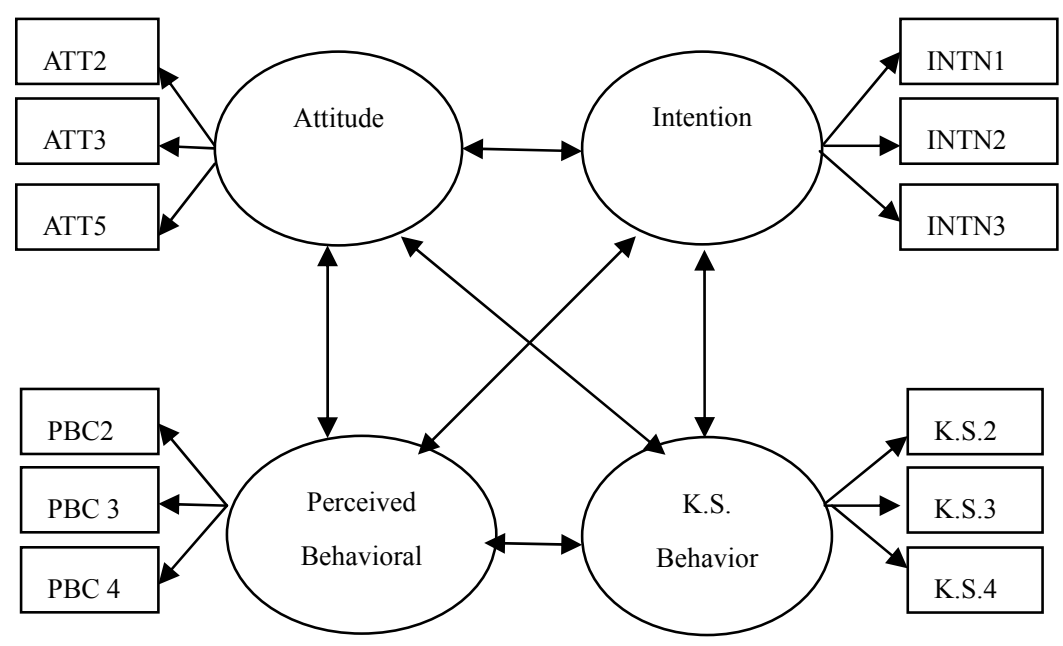

Figure 3. Measurement model after refinement 
The model fit indices are within acceptable ranges: $\chi^{2}=50.557, \mathrm{df}=48, \chi^{2} / \mathrm{df}=1.054$ and $\mathrm{p}=0.372, \mathrm{GFI}=0.963$, $\mathrm{CFI}=0.997$, and RMSEA $=0.016$ (Hair et al., 2014). Convergent validity measured by factor loadings showed items readings well above .7, variance extracted showed all items are above 0.5, the standard threshold (Byrne, 2010 ) and reliability readings are all above 0.6 (attitude $=0.718$; perceived behavioural control $=0.608$; behavioural intention $=0.825$; knowledge sharing behaviour $=0.802)$. Discriminant validity tested using the average variance extracted (AVE) method (Table 2). The findings indicate acceptable discriminant validity (Hair, Black, Babin, \& Anderson, 2006).

Table 2. Squared correlation matrix

\begin{tabular}{lllll}
\hline & Intentions & K.S. Behaviour & Attitude & Perceived behavioural Control \\
\hline Intentions & $\mathbf{. 6 1 0}$ & & & \\
K.S. Behaviour & .441 & $\mathbf{. 5 8 6}$ & & \\
Attitude & .243 & .201 & $\mathbf{. 5 6 0}$ & \\
Perceived Behavioural Control & .328 & .254 & .179 & $\mathbf{. 5 8 2}$ \\
\hline
\end{tabular}

Note. Average variances extracted are on the diagonal. The values below the diagonal are the squared correlations between the constructs.

\subsection{Structural Model}

Running the confirmatory factor analysis showed acceptable model fit indices: $\chi^{2}=85.711, \mathrm{df}=50, \chi^{2} / \mathrm{df}=1.714$, $\mathrm{GFI}=0.941, \mathrm{CFI}=0.965$, and RMSEA $=0.057$. With subjective norms elimination at the measurement model level, only two behavioural beliefs are tested, attitude and perceived behavioural controls. The structural paths regression weight output show all paths are significant, except for the path from perceived behavioural controls (PBC) and knowledge sharing behaviour (Table 3)

Table 3. Path estimations for hypothesised model

\begin{tabular}{lllll}
\hline Path & Estimate & Standard Error & Critical Ratio & P value \\
\hline Attitude- Intention & .248 & .050 & 4.958 & $* * *$ \\
PBC- Intention & .345 & .065 & 5.329 & $* * *$ \\
Intention - K.S. behaviour & .586 & .096 & 6.082 & $* * *$ \\
PBC- K.S. behaviour & .134 & .072 & 1.869 & .062 \\
\hline
\end{tabular}

Note. ${ }^{* * *} \mathrm{p}<0.001$.

The standardised direct effect (Table 4) show that perceived behavioural controls impact on behaviour intention exceeds the impact of attitude on behavioural intention (.487 vs. .383). As well, perceived behavioural controls have a higher impact compared to attitude impact on knowledge sharing behaviour through intentions (.326 vs. 257).

Table 4. Standardised total effect

\begin{tabular}{lllll}
\hline & Attitude & PBC & Intention & K.S. behaviour \\
\hline Intention & .383 & .487 & .000 & .000 \\
K.S. behaviour & .257 & .326 & .670 & .000 \\
\hline
\end{tabular}

\subsection{Gender Moderating Effect}

Models for gender group files were first tested separately to examine structural model fit for each group. Results showed an adequate model fit indices for the males group: $\chi^{2}=53.287, \mathrm{df}=51, \chi^{2} / \mathrm{df}=1.045$, GFI $=0.940, \mathrm{CFI}=$ 0.996 , and RMSEA $=0.018$. All paths in the males structural model were significant. Females' model showed an adequate model fit indices: $\chi^{2}=79.720, \mathrm{df}=51, \chi^{2} / \mathrm{df}=1.563$, GFI $=0.906, \mathrm{CFI}=0.924$, and RMSEA $=0.047$. However, the attitude-intention path was insignificant. Having established a good fit for both files separately, a check of the model fit for both samples together also produces a good fit: $\chi^{2}=138.156, \mathrm{df}=102, \chi^{2} / \mathrm{df}=1.354$, $\mathrm{GFI}=0.909, \mathrm{CFI}=0.960$, and RMSEA $=0.041$ allowing to proceed with group invariance analysis. All $\Delta \mathrm{CFI}$ values were below .01 (Byrne, 2010) indicating invariance between gender groups, which means that the model 
is operating equivalently across males and females. Tables 6 represent the path un-standardised regression weights for both groups.

Table 5. The un-standardised path estimates and critical ration for both genders

\begin{tabular}{lllllll}
\hline Paths & \multicolumn{2}{c}{ Females } & \multicolumn{3}{c}{ Males } & \\
\cline { 2 - 7 } & Estimates & Critical ratio & $\mathrm{P}$ & Estimates & Critical ratio & P \\
\hline Attitude -intention & .125 & 1.151 & $\mathrm{n} / \mathrm{s}$ & .470 & 4.443 & $* * *$ \\
PBC- intention & .507 & 4.519 & $* * *$ & .310 & 4.007 & $* * *$ \\
Intention - K.S. behaviour & .564 & 4.544 & $* * *$ & .715 & 6.994 & $* * *$ \\
\hline
\end{tabular}

Note. $* * * \mathrm{p}<.001$

The standardized total effect output revealed that perceived behavioural controls impact on intention is higher for females compared to males (.595 vs. .439) in addition to its total effect on knowledge sharing behaviour (.337 vs. .309). The total effect on knowledge sharing is lower than the results of (67\%) for the entire sample (Table 4).

\section{Discussion}

The data analysis finds support only for H1, H3, H5.1 and H5.3; however, no support is found for H2, H4, and H5.2. In other words, attitude and perceived behavioural controls positively impact behavioural intention, whereas the impact of subjective norms on intentions and perceived behavioural controls direct impact on knowledge sharing behaviour is not supported. The results indicate that perceived behavioural controls and attitudinal beliefs are the two key determinants of knowledge sharing behavioural intentions among Jordanian commercial banks' personnel. Subjective norms variable, others' expectations, opinions, practices and approval of knowledge sharing is not an influential variable in the model. Literature reports voluntariness moderates and impairs the relationship between subjective norms and intentions; whereas under involuntary situations, subjective norms impact intentions as a result of compliance with managerial or organizational demand (Armitage \& Conner, 2001; Sun \& Zhang, 2006). In the current paper, respondents indicate that knowledge sharing is a voluntary act on their side. Another possible explanation lies with the sample demographics, 54\% of the sample performs managerial roles and $70 \%$ enjoy more than 5 years experience in banking, literature reports that the impact of subjective norms on the behavioural intentions tends to attenuate over time with gained experience (Venkatesh, Morris, G. Davis, \& F. Davis, 2003, Venkatesh \& Bella, 2008).

The findings also report perceived behavioural controls as the key determinant of knowledge behavioural intentions. Ajzen (1991) stated that the relative importance of the three variables (attitude, subjective norms, and PBC) in predicting behavioural intentions would vary across behaviours and situations; when attitude is strong and subjective norms are powerful, perceived behavioural controls become less predictive of intentions (Armitage \& Conner, 2001). The current findings present the opposite scenario; subjective norms were not powerful enough to predict intentions and attitude was also secondary in predicting intentions, hence perceived behavioural controls stepped in as a key predictor of intentions. The findings also found no support for PBC direct impact on knowledge sharing behaviour. According to Ajzen (1991), under volitional control, PBC will have no direct impact on behaviour. Respondents indicated that employees' voluntary share individual know-how, effective information and knowledge with each other, which explains why perceived behavioural control have no direct impact on sharing behaviour. Findings demonstrated that attitude is not a beahvioural intention determinant among females and that PBC presents the key determinant of knowledge behaviour through intentions for female respondents. Literature on TPB reports that attitude towards behaviour is more salient for men while perceived behavioural controls are more salient for females (Venkatesh et al., 2000; Venkatesh \& Morris, 2000). A possible explanation for females' lack of attitude towards sharing intentions might lie with the social and cultural ties in Jordanian society. Although females are assuming managerial roles in banks, it is a highly competitive environment. According to general statistics, females comprised 33\% of banking jobs in Jordan (Department of Statistics, 2012). Cross tabulation of gender and banking job titles for the current sample revealed that from the $36 \%$ females in the sample only $19.3 \%$ assumed managerial roles, whereas $34 \%$ males assumed the same managerial roles. Females feel the need to prove themselves in a male dominant society and be competitive. However, this area of research is not investigated in literature.

The current research findings are congruent in general with literature on knowledge sharing behaviour under the umbrella of social psychology theories TRA and TPB. Although PBC was added to accounts for none volition behaviours, or situations where individuals lack complete control over the behaviour, the author of TPB 
acknowledges that this lack of control manifest in the lack of direct impact on the behaviour under consideration. However, PBC still impact the behaviour through behavioural intentions. The findings revealed that sharing intentions through the two key determinants, attitude and perceived behavioural control, explain only $67 \%$ of variance in knowledge sharing behaviour for the sample (Table 4) and for females' model the percentage is only $31 \%$. Apparently, females' have other motivators for knowledge sharing in an organizational context, an area worth exploring in future research.

\section{Limitations and Future Research}

Limitations need to be considered with interpretation of findings. First, the study is a cross-sectional investigation and this limits the generalizability of findings. A longitudinal approach might give an insight how determinants of sharing behaviour change overtime. Second, the results are confined to knowledge sharing behaviour with the Jordanian commercial banks, it may not be confirmed when examined in none Jordanian commercial banks in Jordan simply due to differences in management style and cultural context. Third, the sharing behaviour is examined under the umbrella of TPB model were findings are limited to the model beliefs' structure and does not take into consideration other factors that may inhibit the behaviour such as personal factors. Finally, the variables of the model were measures using self-report design, which means that the results may be influenced by common method bias or social desirability tendency that might have distorted the mean for samples information. Further research is needed to find out why females hold a non-positive attitude towards sharing intentions. The effect of other variable such as trust, cultural values, and competitiveness should be investigated to understand females' propensity to share.

\section{Conclusion}

Knowledge sharing is an important part of knowledge management and its success depends on how much knowledge is utilized among personnel. The finding suggest that practitioners in Jordanian banking sector need to work on creating a favourable attitude towards knowledge sharing behaviour among personnel, perhaps through administering a reward or incentive system for outstanding employees who tend to share their know-how and effective information with others. Apparently, practitioners might emphasise different incentives for females to improve their propensity to sharing knowledge with others in the work environment.

\section{Acknowledgements}

The authors are grateful to the Applied Science Private University, Amman, Jordan, for the financial support granted to cover the publication fees of this research article.

\section{References}

Ahmadi, S. A., Daraei, M. R., \& Kalam, R. F. (2012). Analysis of knowledge sharing in banking industry. Interdisciplinary Journal of Contemporary Research in Business, 4(7), 815-827.

Ajzen, I., \& Fishben, M. (1980). Understanding attitude and predicting social behaviour. Englewood Cliffs, NJ: Prentice Hall.

Ajzen, I. (1985). From Intentions to Actions: A Theory of Planned behaviour. In J. Khul \& J. Beckmann (Eds.), Action-Control: from cognition to behaviour (pp. 11-39). Heidelberg, Germany: Springer. http://dx.doi.org/10.1007/978-3-642-69746-3_2

Ajzen, I. (1991). The theory of planned behaviour. Organizational Behaviour and Human Decision Processes, 50(2), 179-211. http://dx.doi.org/10.1016/0749-5978(91)90020-T

Ajzen, I. (2002). Perceived behavioural control, self-efficacy, locus of control, and the theory of planned behaviour. Journal of Applied Social Psychology, 32(1), 1-20.

Ajzen, I. (2006). Theory of Planned Behaviour. Retrieved from http://people.umass.edu/aizen/tpb.html

Alhalhouli, Z. T., Hasan, Z. B., \& Der, C. S. (2014). Factors affecting knowledge sharing behavior among stakeholders in Jordanian hospitals using social networks. International Journal of Computer and Information Technology, 3(5), 919-928.

Argote, L., \& Ingram, P. (2000). Knowledge transfer: A basis for competitive advantage in firms. Organizational Behaviour and Human Decision Processes, 82(1), 150-169. http://dx.doi.org/10.1006/obhd.2000.2893

Armitage, C. J., \& Conner, M. (2001). Efficacy of the Theory of Planned Behaviour: A meta-analytic review. British Journal of Social Psychology, 40(4), 471-499. http://dx.doi.org/10.1348/014466601164939

Arora, R. (2002). Implementing KM-A balanced score card approach. Journal of Knowledge Management, 6(3), 240-249. http://dx.doi.org/10.1108/13673270210434340 
Awad, E. M., \& Ghaziri, H. M. (2007). Knowledge Management (6th ed.). New Delhi: Pearson Education-South Asia.

Bender, S., \& Fish, A. (2000). The Transfer of Knowledge and the Retention of Expertise: The Continuing Need for Global Assignments. Journal of Knowledge Management, 4(2), 125-137. http://dx.doi.org/10.1108/13673270010372251

Bock, G. W., \& Kim, Y. G. (2002). Breaking the myths of rewards: An Exploratory Study of Attitudes about Knowledge Sharing. Information Resources Management Journal, 15(2), 14-21. http://dx.doi.org/10.4018/irmj.2002040102

Bock, G. W., Zmud, R. W., Kim, Y. G., \& Lee, J. N. (2005). Behavioural intention formation in knowledge sharing: examining the role of extrinsic motivators, social-psychological forces, and organizational climate. MIS Quarterly, 29(1), 87-111.

Byrne, B. M. (2010). Structural Equation Modelling with AMOS (2nd ed.). New York, NY: Routledge.

Chatzoglou, P. D., \& Vraimaki, E. (2009). Knowledge sharing behaviour of bank employees in Greece. Business Process Management Journal, 15(2), 245-266. http://dx.doi.org/10.1108/14637150910949470

Connelly, C. E., \& Kelloway, E. K. (2003). Predictors of employees' perceptions of knowledge sharing cultures.

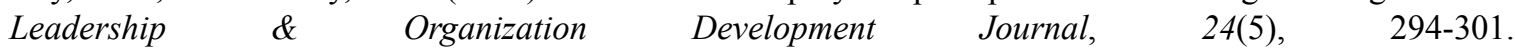
http://dx.doi.org/10.1108/01437730310485815

Cross, R., Parker, A., \& Borgatti, S. P. (2002). A Bird Eye's View: Using Social Network Analysis to Improve Knowledge Creation and Sharing. IBM Institute of Business Value. Retrieved from $\mathrm{http}: / / \mathrm{www}-07 . \mathrm{ibm} . \mathrm{com} / \mathrm{services} / \mathrm{hk} / \mathrm{strategy} / \mathrm{e} \_$strategy/social_network.html

Department of Statistics. (2013). Jordan statistic year book. Retrieved from http://www.dos.gov.jo/dos_home_a/main/yearbook_2013.pdf

Dunford, R. (2000). Key challenges in the search for the effective management of knowledge in management consulting firms. Journal of Knowledge Management, 4(4), 295-302. http://dx.doi.org/10.1108/13673270010379849

Frost, A. (2014). A synthesis of knowledge management failure factors. Retrieved from http://www.knowledge-management-tools.net

Grandori, A., \& Kogut, B. (2002). Dialogue on organisation and knowledge. Organisation Science, 13(3), 224-231. http://dx.doi.org/10.1287/orsc.13.3.224.2774

Goman, C. (2002). What leaders can do to foster knowledge sharing. Knowledge Management Review, 5(4), $10-11$.

Hair, J. F., Black, W. C., Babin, B. J., \& Anderson, R. E. (2014). Multivariate Data Analysis: International edition (7th ed.). Essex- England: Pearson Education.

Hislop, D. (2003). Linking human resource management and knowledge management via commitment: A review and research agenda. Employee Relations, 25(2), 182-202. http://dx.doi.org/10.1108/01425450310456479

Ipe, M. (2003). Knowledge sharing in organizations: A conceptual framework. Human Resource Development Review, 2(4), 337-359.

Jeon, S., Kim, Y. G., \& Koh, J. (2011). An integrative model for knowledge sharing in communities-of-practice. Journal of Knowledge Management, 15(2), 251-269. http://dx.doi.org/10.1108/13673271111119682

Kelloway, E. K., \& Barling, J. (2000). Knowledge work as organizational behaviour. International Journal of Management Reviews, 2(3), 287-304.

Lin, H. F., \& Lee, G. G. (2004). Perceptions of senior managers toward knowledge-sharing behaviour. Management Decision, 42(1), 108-125. http://dx.doi.org/10.1108/00251740410510181

Lin, H. F. (2007). Effects of extrinsic and intrinsic motivation on employee knowledge sharing intentions. Journal of Information Science, 33(2), 135-149. http://dx.doi.org/10.1177/0165551506068174

Luethge, D. J., \& Byosiere, P. (2007). Japanese corporations: gender differences in re-defining tacit knowledge. Women in Management Review, 22(1), 33-48. http://dx.doi.org/10.1108/09649420710726210

Mahmood, A., Qureshi, M. A., \& Shahbaz, Q. (2011). An examination of the quality of tacit knowledge sharing through the theory of reasoned action. Journal of Quality and Technology Management, 7(1), 39-55. 
Martensson, M. (2000). A Critical Review of Knowledge Management as a Management Tool. Journal of Knowledge Management, 4(3), 204-216. http://dx.doi.org/10.1108/13673270010350002

Miller, K. (2004). Communications theories: Perspectives, processes, and contexts (2nd ed.). New York, NY: McGraw-Hill.

Miller, R. (2002). Motivating and Managing Knowledge Workers. Knowledge Management Review, 5(1), 16-21.

Morris, M. G., Venkatesh, V., \& Ackerman, P. L. (2005). Gender and age differences in employee decisions about new technology: An extension to the theory of planned behaviour. IEEE Transactions on Engineering Management, 52(1), 69-84. http://dx.doi.org/10.1109/TEM.2004.839967

O'Dell, C., \& Grayson, C. J. (1998). If only we knew what we know: identification and transfer of internal best practices. California Management Review, 40(3), 154-174. http://dx.doi.org/10.2307/41165948

Sawng, Y. W., Kim, S. H., \& Han, H. S. (2006). R\&D group characteristics and knowledge management activities: A comparison between ventures and large firms. International Journal of Technology Management, 35(1-4), 241-261. http://dx.doi.org/10.1504/IJTM.2006.009237

Sheppared, B. H., Hartwick, J., \& Warshaw, P. R. (1988). The theory of reasoned action: A Meta analysis of past research with recommendations for modification and future research. Journal of Consumer Research, 15(3), 325-343.

Smith, E. A. (2001). The role of tacit and explicit knowledge in the workplace. Journal of Knowledge Management, 5(4), 311-321. http://dx.doi.org/10.1108/13673270110411733

Sun, H., \& Zhang, P. (2006). The role of moderating factors in user technology acceptance. International Journal of Human-Computer Studies, 64(2), 53-78. http://dx.doi.org/10.1016/j.ijhcs.2005.04.013

Taylor, W. A. (2004). Computer-mediated Knowledge Sharing and Individual User Differences: An Exploratory Study. European Journal of Information Systems, 13(1), 52-64. http://dx.doi.org/10.1057/palgrave.ejis.3000484

Wah, L. (1999). Making knowledge stick. Management Review, 88(5), 24-29.

Wang, K., Hjelmervik, O. R., \& Bremdal, B. (2001). Introduction to knowledge management: Principles and Practice. Trondheim: Tapir academic press.

Wang, S., \& Noe, R. A. (2010). Knowledge sharing: A review and direction for future research. Human Resource Management Review, 20(2), 115-131. http://dx.doi.org/10.1016/j.hrmr.2009.10.001

Venkatesh, V., \& Morris, M. G. (2000). Why don't men ever stop to ask for directions? Gender, social influences, and their role in technology acceptance and usage behaviour. MIS Quarterly, 24(1), 115-139.

Venkatesh, V., Morris, M. G., \& Ackerman, P. L. (2000). A longitudinal field investigation of gender differences in individual technology adoption decision-making processes. Organizational Behavior and Human Decision Processes, 83(1), 33-60. http://dx.doi.org/10.1006/obhd.2000.2896

Venkatesh, V., Morris, M. G., Davis, G. B., \& Davis, F. D. (2003). User acceptance of information technology: Toward a unified view. MIS Quarterly, 27(3) 425-478.

Venkatesh, V., \& Bala, H. (2008). Technology acceptance model 3 and a research agenda on interventions. Decision Sciences, 39(2), 273-315. http://dx.doi.org/10.1111/j.1540-5915.2008.00192.x

Yang, J. (2008). Individual attitude and organisational knowledge sharing. Tourism Management, 29(2), 345-353. http://dx.doi.org/10.1016/j.tourman.2007.03.001 


\section{Appendix: Variables operational definition}

\begin{tabular}{|c|c|}
\hline Variable & Scale measures \\
\hline \multirow[t]{5}{*}{ Attitude } & ATT1: My KS with others in bank is good. \\
\hline & ATT2: My KS with other bank members is enjoyable. \\
\hline & ATT3: My KS with other bank members is harmful. \\
\hline & ATT4: My KS with other bank members is valuable for me. \\
\hline & ATT5: My KS with other bank members is a wise move. \\
\hline \multirow[t]{4}{*}{ Subjective Norms } & SN1: It is expected of me that I share my knowledge. \\
\hline & SN2: Most colleagues that are important to me believe I should share my knowledge with others. \\
\hline & SN3: Most colleagues that are important to me share their knowledge with others. \\
\hline & SN4: Colleagues, whose opinion I value, would approve of my knowledge-sharing with others. \\
\hline Perceived Behavioural & $\mathrm{PBC} 1$ : For me to share my knowledge is always possible. \\
\hline \multirow[t]{3}{*}{ Controls } & PBC2: If I wanted to, I could always share my knowledge. \\
\hline & PBC3: It is mostly up to me whether or not I share knowledge with others. \\
\hline & PBC4: I believe there is much control I have to share my knowledge with others. \\
\hline \multirow[t]{4}{*}{ Behavioural Intentions } & INTN1: I will share my knowledge with other organizational members. \\
\hline & INTN2: I will always provide my knowledge at the request of others. \\
\hline & INTN3: I intend to share my knowledge with others at bank in future. \\
\hline & INTN4: I will share my knowledge with anyone at the bank if it is helpful for work. \\
\hline Knowledge & KS1: Employees can freely access majority of documents, information and knowledge within the bank. \\
\hline \multirow[t]{3}{*}{ Behaviour } & KS2:Employees voluntary share individual know-how, effective information and knowledge with each other \\
\hline & $\begin{array}{l}\text { KS3: My department uses various database frequently to improve the quality of operations flow involving other } \\
\text { departments }\end{array}$ \\
\hline & $\begin{array}{l}\text { KS4: My department motivation policy encourages employees to make recommendations for improvement and } \\
\text { exchange experience with others. }\end{array}$ \\
\hline
\end{tabular}

\section{Copyrights}

Copyright for this article is retained by the author(s), with first publication rights granted to the journal.

This is an open-access article distributed under the terms and conditions of the Creative Commons Attribution license (http://creativecommons.org/licenses/by/3.0/). 